\title{
FOCALIZANDO O TRAUMA SOB AS LENTES DA CLÍNICA COM POLICIAIS MILITARES
}

Silvia Lira Staccioli Castro

Esta tese é um estudo sobre o trauma e seus efeitos sob um viés dinâmico, e não meramente econômico, enfatizando o funcionamento sádico do supereu na neurose traumática, tendo como referência a observação clínica. Assim, além das noções de Schreck (susto) e do excesso de estímulo pulsional, apresentados por Freud em 1920 para explicar o trauma, incluiremos nesta pesquisa o papel do supereu, cuja imposição do gozo - masoquista - a serviço da pulsão de morte pode levar à compulsão à repetição do trauma.

\section{BANCA:}

Ana Maria Rudge (Orientadora)

Anna Carolina Lo Bianco Clementino

Betty Bernardo Fuks

Francisco Moacir de Melo Catunda Martins

Heloisa Fernandes Caldas Ribeiro

Data da defesa: 13/03/2009 